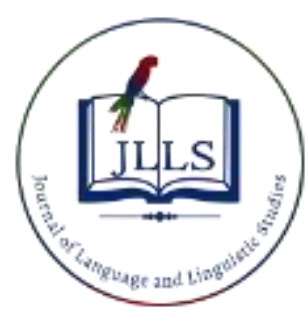

Available online at www.jlls.org

JOURNAL OF LANGUAGE AND LINGUISTIC STUDIES

ISSN: $1305-578 \mathrm{X}$

Journal of Language and Linguistic Studies, 16(2), 1043-1057; 2020

\title{
Violation of Grice's maxims and humorous implicatures in the Arabic comedy Madraset Al-Mushaghbeen
}

\author{
Hameed Yahya A. Al-Zubeiry ${ }^{\text {al }}$ \\ ${ }^{a}$ Al-Baha University, Baljurashi, KSA
}

\section{APA Citation:}

Al-Zubeiry, H. (2020). Violation of Grice's maxims and humorous implicatures in the Arabic comedy Madraset Al-Mushaghbeen. Journal of Language and Linguistic Studies, 16(2), 1043-1057.

Submission Date: $27 / 02 / 2020$

Acceptance Date:14/04/2020

\begin{abstract}
The aim of this paper is to explore the violation of Grice's Maxims in the Arabic comedy Madraset AlMushaghbeen and explain how the violation of the maxims brings about humorous effects in the play. The analysis shows that 61 instances of maxims violation were identified in the play. Maxim of Manner receives the highest percentage of violation i.e., 24 (39.3\%) compared to the other maxims. Maxims of Relevance and Quality come next, i.e., 14 (22.9\%) and 13 (21.4\%). Maxim of Quantity constitutes 10 number of violations (i.e., 21.4\%). The study shows that most of maxim violations that create humorous situations are perceived through the following: rhetorical strategy of overstatement and personification, use of misleading conventional-coded expressions, incongruity of conversation-established concepts/ideas, and breaking of communication norms. The study also reveals that cultural and background knowledge significantly contribute to eliciting the humorous implicatures from the characters' utterances. The study concluded with the following implications: humorous implicature depends on the conventions of the speakers' community and the language shared among them; and it arises as a result of speakers' acts and/or expressions that tend to be incongruous with the behavior and concepts established in the culture of the concerned interlocutors.
\end{abstract}

(C) 2020 JLLS and the Authors - Published by JLLS.

Keywords: violation; Grice's maxims; humorous implicatures; comedy; cooperative principle

\section{Introduction}

In social interaction, language is used as a code for communicating and expressing interlocutors' thoughts, feelings, and emotions, and for establishing and maintaining their social relationships. An effective interaction requires that the involved participants be cooperative with each other. Grice (1975) posits four conversational maxims in his Cooperative Principle (CP) to be observed by the interlocutors to ensure successful interaction. These maxims are the 'Maxim of Quality' (be truthful), the 'Maxim of Quantity' (be informative) the 'Maxim of Relation' (be relevant), and the 'Maxim of Manner' (be clear). The main underlying assumption of the cooperative principle is that people cooperate when they are conversing" (Thomas, 1995, p. 62).

\footnotetext{
${ }^{1}$ Corresponding author. Tel.: +00966177220601- Extension: 193

E-mail address: halzubeiry@bu.edu.sa / hameedyahya@gmail.com
} 
Grice (1975) points out that in some conversational interaction, interlocutors do not follow the maxims in their conversation. They intentionally violate the maxims in order to communicate extra or implied meaning. According to him, violation of any maxim creates conversational implicatures; and it is the task of the hearer to infer the implied additional meaning. Apart from the possible created implicatures, violation of a maxim can bring about humorous effects in the spoken discourse (Taberski, 1998). Consider the following interaction between two Arabic speaking students studying history for the exam. Student A: what did the Romans do after getting out of the sea? Student B: they wrung their clothes dry. It is obvious that student B violates the maxim of quantity as he does not give enough information. He at the same time creates an implicature, which can be interpreted as that he does not know the answer. Another motivation for violating this maxim is to create a sense of humor in the produced spoken discourse.

A number of researchers have considered the motivations for using implicature in conversational interaction (Leech, 1983; Brown \& Levinson, 1987; Chen, 1993). Leech (1983) and Brown and Levinson (1987) hold the view that interlocutors tend to show being polite in their conversation in order to maintain social and friendly relationship. According to them, an interlocutor motivated by the 'Politeness Principle' would tailor what and/or how something is said to the particulars of a situation in order to appear polite. For instance, an airport attendant approaching a passenger smoking at 'No Smoking Zone' says: 'smoking is not allowed here'. The implicature of such an utterance is a polite indirect request asking the passenger to refrain from smoking in this zone.

Another motivation for using implicature is proposed by Chen (1993) in his 'Self-interest Principle'. This principle holds that what and/or how speakers say things is motivated by a desire to avoid the negative, consequences of what they say. Chen (1993) states that "(b)y its very nature, language commits its users to whatever they say" (p. 62). A person, for example, asks his classmate the whereabouts of the biology teacher and the response is 'He is in the teachers' room. Here the informer becomes committed to the belief that the teacher is in the teachers' room; and if it happens that the questioner goes and he does not find the teacher there, then the questioner will have the right to accuse the informer of saying something not true. Chen (1993) also formulated the 'Expressiveness Principle'. This principle governs the use of implicature when 'the speaker (or poet) has strong emotions about the things being conveyed and wants to pass on these emotions to the hearer, "leaving as much impact, psychological, aesthetic, or otherwise as possible..." (Chen, 1993, p. 63).

Conversational implicature has been used to create humor in different genres, namely jokes, wit, comedies and television shows (Yamaguchi, 1988; Dolitsky, 1992; Hunter, 1983; Taberski, 1998, Al kayed, 2019). A speaker deliberately violates any maxim of CP just to bring about humorous implicature the underlying effect of which lies in its purpose of eliciting laughter and amusement. However, it should be pointed out that the humorous effect of implicature depends on factors like culture, convention and language owned by different speech communities (Leech, 1983). In Arabic speaking community, for instance, a speaker's implied humorous utterance can be inferred by a hearer/s sharing the same factors.

\subsection{Aims of the Study}

In light of the above-mentioned background, the aims of the present study are formed. They are as follows:

-exploring the violations of Grace's maxims in the Arabic comedy Madraset Al-Mushaghbeen; -counting the violations of Grice's maxims in the play; and

-explaining how the violations of the maxims create humorous effects in the play. 


\subsection{Literature Review and Previous Related Studies}

\subsubsection{Cooperative Principle}

The cooperative principle was proposed by the British philosopher Paul Grice in his works in 1940s and 1950s. According to him, in order for a conversation take place smoothly, a speaker is expected to observe the cooperative principle that ensures successful interaction. Grice summaries his $\mathrm{CP}$ in these words: "(m)ake your contribution such as required, at the stage at which it occurs, by the accepted purpose or direction of the talk exchange in which you are engaged" (Grice, 1975, p. 45). Thomas (1995) elucidates Grice's CP in that she states "people who are involved in a conversation are working on the assumption that certain rules control their operation, i.e., a set of culturally bound rules that vary in different cultures but are followed by all the participants of a conversation in order for a conversation to be successful" (p. 62).

Grice suggested that for a conversation, interlocutors unconsciously adhere to four maxims that are subsumed under the cooperative principle (Thomas, 1995, p. 65). These maxims are:

1. Maxim of Quantity

i- Make your contribution as informative as required (for the current purposes of the talk exchange).

ii- Do not make your contribution more informative than is required.

2. Maxim of Quality-Try to make your contribution one that is true.

i- Do not say what you believe to be false.

ii- Do not say that for which you lack adequate evidence.

3. Maxim of Relation - Be relevant.

4. Maxim of Manner- Be perspicuous.

i- Avoid obscurity of expression.

ii- Avoid ambiguity.

iii-Be brief (avoid unnecessary prolixity).

iv- Be orderly. (Grice, 1975, pp. 45-46)

\subsubsection{Flouting and Violating Conversational Maxims}

According to Grice (1975), it is expected that interlocutors in a conversation follow the maxims of cooperation. However, they sometimes fail to obey or follow these maxims for certain choices. These choices are considered in terms of flouting and violating conversational maxims. Flouting a maxim is a situation when "a speaker blatantly fails to observe a maxim" (Thomas, 1995, p. 65). The speaker does not have any intention to mislead or deceive the hearer, but he expects the hearer to infer an implied meaning that is different from the expressed one. Violating a maxim, on the other hand, is a situation when a speaker fails to obey a conversational maxim in order that to intentionally generate misleading implicature in a conversation (Thomas, 1995, p.73). A speaker is said to violate a conversational maxim when he knows that the hearer will not know the truth and will only know the expressed meaning of what is said. To put it differently, the speaker intentionally misleads and deceives the hearer. Such situations give rise to conversational implicature whereby a speaker creates a special force to his utterance that brings about effect other than the literal meaning of the words uttered. The effect of the speaker's utterance can be realized in its purpose of eliciting laughter and amusement.

\subsubsection{Implicature}

The term implicature describes something that is conveyed beyond the semantic meaning of the words in a conversation. Grice (1975) distinguished between two types of implicature, namely conversational implicature and conventional implicature. According to him, a conventional implicature is derived from the literal meaning of the words uttered to determine what is implied. The following 
example given by Grice (1975, p. 44) illustrates this point: 'He is an Englishman; he is, therefore brave'. By virtue of the use of the word 'therefore', it is implied that the person's being brave stems from the fact that he is an Englishman. Thomas (1995, p. 57) refers to four words that function as triggers for implicature on the sentence level: 'but, even, therefore, and yet'. She gave an example explaining the conventional implicature in the utterance: 'She was cursed with stammer, unmarried but far from stupid'. Here the word ' $b u t$ ' functions as contrasting the expectations that unmarried people are usually stupid.

A Conversational implicature, on the other hand, is not bound by the literal meaning of the utterance. According to Grice (1975), conversational implicatures can arise from either strictly and directly observing or deliberately and openly flouting the maxims, that is, speakers can produce implicatures in two ways: observance and non-observance of the maxims. The observance of the maxims can be illustrated by the following example. Husband asks his wife: where are the car keys? His wife responds: they are on the table in the hall. Here it can be noticed that the wife has observed the four maxims of conversation. She has answered clearly (Maxim of Manner) and truthfully (Maxim of Quality), has given just the right amount of information (Maxim of Quantity) and has directly addressed her husband's goal in asking the question (Maxim of Relation). She has said precisely what she meant, no more and no less. As for non-observance of the maxims, we can consider the following scenario (Yule, 1996, p.36). There is a woman sitting on a bench and a large dog lying on the ground in front of the bench. A man comes along and sits down on the bench. Man: Does your dog bite? Woman: No. (The man reaches down to pat the dog). The dog bites the man's hand. Man: Quch! Hey! You said your dog doesn't bite. Woman: He doesn't. But that's not my dog. Asking the question, the man assumes that the dog belongs to the woman. The woman's answer provides less information than expected. The maxim of quantity is flouted. The implicature that can be figured out is that the woman is not willing to talk with the man.

\subsubsection{Humor in Discourse}

Humor is defined as a form of communication that evokes the reflex of laughter in people (Benton [ed], 1983, p. 7). It is related to anything done, written or spoken with the purpose of arousing laughter or amusement in whosoever experiences it. Humorous spoken discourse can be created by the violation of principles of communication suggested by pragmatic principles, both textually and interpersonally. According to Grice (cited in Attardo, 1994, pp. 271-276), humorous situations emerge as the interlocutors do not obey the $\mathrm{CP}$ and its maxims by violating the rules.

Humorous discourse and the way it is processed can be explained with reference to a number of humor theories. Superiority theory, relief theory and incongruity theory are the most relevant and prominent ones. According to the superiority theory, laughter arises from our sense of superiority with respect to someone else. The laugher always looks down on whatever he laughs at. Hobbes (cited in Attardo, 1994, p. 49) suggests that "laughter arises from a sense of superiority of the laugher towards some object." The relief/release theory is basically based on the idea that humor is used to release tension or psychic energy (Attardo, 1994, p. 50). The proponents of this theory believe that people experience a pleasant sensation when humor replaces negative feelings like pain or sadness (Schwarz, 2010, p. 51). The incongruity theory is the most influential one for the study of humor. According to this theory, humor happens at the moment of realization of incongruity between a concept involved within certain context and the real objects thought to be related in somehow to the concept (Schwarz, 2010, p. 52). Schopenhauer (cited in Attardo, 1994, p. 48) maintains "[t]he cause of laughter in every case is simply the sudden perception of the incongruity between an established concept and a real object which have been connected by some relation, and the laugh itself is just an expression of this."

As the purpose of the present study is to explain how the violations of the maxims create humor in the comedy, Madraset Al-Mushaghbeen, incongruity theory is considered more relevant as the violation of Grice's conversational maxims is an act incongruous with the behavior expected of the interlocutors. 
Grice's CP expresses the condition that interlocutors observe the submaxims, and if they do not, then it is to convey some no-literal meaning by their utterance and not because they have opted out of the conversation.

A number of related previous studies concerning the violations of Grice's maxims and humorous effects in different genres were conducted. Taberski (1998), for instance, analyzed the situation comedy (Friends) with reference to Gricean maxims. The study aimed at investigating what part of the humor in sitcoms that can be attributed to violations of Grice's Maxims and second, to possibly amend the list of established motivations for using implicature with its effect of eliciting laughter. The researcher showed evidence of the humorous violation of Grice's Maxims within the sitcom (Friends). He also confirmed that Grice offered a useful tool for explaining some of the humorous effects to which language is put. The researcher showed instances of humor, specifically those found in a situation comedy, to come from implicature involving violations of all four of Grice's Maxims.

Another study was conducted by Ahmed (2007). The aim of the study was to find a relationship between humorous discourse and Gricean maxims. Some Arabic texts were selected for the analysis. The findings of the study showed that the violations of the maxims are interdependent, and that the maxim of relevance subsumes the other three maxims: Quantity, Quality and Manner.

Hu (2012) studied the verbal humor in the "Big Bang Theory" with reference to the Cooperative Principle and the Relevance Theory. The findings of the study indicated that humor is created when any of the four cooperative maxims is violated or flouted. As for the framework of the relevance theory, the findings showed that humor is viewed as an ostensive-inferential process. The study suggested that these theories are efficient in accounting for the creation of comic effects.

Hassan (2013) explored how and why Egyptians in their revolution of $25^{\text {th }}$ of January and the Americans in Occupy Wall Street Movement use humor. The study attempted to pinpoint how humor can be used as a strategy of nonviolent resistance to oppression and dictatorship. It recognized the nature of humor based on Grice's Cooperative Principles and speech act theory. It also investigated the similarities and differences in the two events. The findings of the study proved that humor is a form of resistance.

A recent study has been conducted by Al Kayed (2019). It aimed at exploring the violations of Grice's maxims in Jordanian jokes. The study focused on identifying the implied meaning of the violated maxims in these jokes and recognizing the factors that affect the interpretation of these jokes. The sample of the study consisted of six jokes selected from WhatsApp and Facebook. The data of the study was categorized with reference to the type of violation. The results of the study showed that Jordanians violate the maxims to create laughter and to communicate social and economic meanings.

As shown in the previous reviewed studies a number of researchers have contributed in investigating how humor is created when Grice's maxims are violated in different genres, namely jokes, posters, sitcoms and television shows. However, it has been observed that these researchers refer to few factors accounting for the emergence of humorous situations in the concerned genre. The novelty of this study lies in its attempt to explore further factors explaining how violations of Grice's maxims create humorous effects in the play, Madraset Al-Mushaghbeen.

\section{Method}

\subsection{Data Collection}

The study is based on a qualitative descriptive method as it aims at exploring the violations of Grice's $\mathrm{CP}$ in Arabic comedy and describing how such violations create humor. The data was collected from 
the well-known Egyptian comedy, Madraset al-Mushaghbeen (School of Troublemakers). The play was downloaded Online. The researcher transcribed all the utterances that were followed with canned laughter on the part of the audience. The utterances were analyzed carefully. The researcher identified the violations of the maxims and categorized them in number and types. It is worthy to note that the researcher consulted an Egyptian professor in Arabic Literature to account for the violations of the maxims in the play.

\subsection{Madraset Al-Mushaghbeen (School of Troublemakers)}

Madraset Al-Moshaghbeen (School of Troublemakers) is an Egyptian comedy released in 1973. It was celebrated for its highly humorous effects that attracted a large number of Arabic speaking audience. The story of the play is set in a school that has the five most mischievous students in the country (Bahgat, Mursi, Mansour, Lutfi, and Ahmed). These students are known to have continuously failed and retaken their high school exam. The students' constant pranks have forced their ex-teachers quit the school. This leads the school principal (Abdulmoati) to limit the school resources to one class for the five students in order to teach them himself. Later in the play another volunteer she-teacher (Effat) is sent from the ministry to teach the students.

\section{Results and Discussion}

As the present study aims at exploring the violations of Grace's maxims in the Arabic comedy Madraset Al-Mushaghbeen; and counting their occurrences in the play, the researcher carefully analyzed all the utterances followed with laugh tracks. He identified the violations of the concerned maxims and categorized them in number and type. The following table presents the results of the analysis.

Table1. Numbers and Frequency of Violations of Grice's Maxims in the Play

\begin{tabular}{cccc}
\hline No & Maxims & Number of Violations & Frequency of Violations \% \\
\hline 1 & Quantity & 10 & 16.4 \\
\hline 2 & Quality & 13 & 21.4 \\
\hline 3 & Relevance & 14 & 22.9 \\
\hline 4 & Manner & 24 & 39.3 \\
\hline & Total & 61 & $100 \%$
\end{tabular}

The table above shows that the total number of violations of Grace's maxims in the play is 61. Maxim of manner constitutes the highest percentage of violations with a total number of 24 (393\%). This is followed by maxims of relevance and quality, $14(22.9 \%)$ and $13(21.4 \%)$. Maxim of quantity receives 10 numbers of violations with a percentage of $16.4 \%$.

\subsection{Violation of Quantity Maxim}

The Maxim of Quantity deals with how much information is contained in an utterance. Violations of this Maxim are made either by saying too much or too little information. The analysis of the maxim violations in the play shows that it receives the least compared to the other ones (10-16.4\%). The following are some examples illustrating how the maxim is violated by the characters in the play, Madraset Al-Mushaghneen: 


\section{Situation 1: [The principal enters the class finding teacher Almalwani being taken off of} his clothes and worn Red Indians' skirt]

Principal: Mashallah! Mashallah! Aih dah ya astzah eli amltuh fi alostaz almalwani? [Great! Great! (sarcastic words). What is the thing that you did with teacher Almalwani?]

Mursi: Ma hu andak a hu esalu! [Here he is. Ask him. (referring to Almalwani)]

Bahgat: Estanu ba! An haolak kul haja ya beh. [Wait! I will tell you everything, sir.]

Principal: Tafadhel [Speak up, please.]

Bahgat: Ehna kuna adin, Albab kan maftoh, rah dakhal alostaz almalwani, wa ehna adin, wa badeen laenah rah ale'a aljaket, wa ehna adin, wa badeen ale'a alqames, wa ehna adin, wa ehna takhadheina, laenah rah ale'a albantaloun. Beyale'a albantaloun ya beh! Mudares Beyale'a Lina albantaloun fi alfasel ya beh! Wa ehna sughaireen ma narafsh hajah ya beh! (Laugh track) [We were sitting. The door was open. Teacher almalwani entered while we were sitting. Afterwards, we saw him taking off the jacket while we were sitting. Later, he took off his shirt while we were sitting. We got scared. We saw him taking off the trouser. He is taking off his trouser for us, sir! A teacher is taking off his trouser for us in the class, sir! We are little kids, know nothing, sir!]

In the situation above the principal asks the students about the one who had teacher Almalawani take off his clothes and wear funny red Indian skirt. Murshi sarcastically tells the principal to direct his question to the teacher himself. Bahgat volunteered the details of what happened. He reported the situation by a mass of superfluous details. This is manifested in his circumlocutory and evasive speech quoted above. Here the character intentionally violated the maxim of quantity as he gave too much information. The purpose of such maxim violation is likely to confuse the principal and to avoid the accusation of being the ones involved in what happened to teacher Almalwani. The character's rhetorical strategy of overstatement accounts for the humorous effect reflected audiences' canned laughter.

Another example of violating quantity maxim lies in the situation when the character provides less information and as a result of which misunderstanding arises and that renders the audience amused. Consider the following situation:

Situation 2: [The school attendant enters the scene carrying a card to the principal by the name Effat Abdulkareem requesting to meet the principal in the presence of the five mischievous students]

Attendant: Hadhrat alnadher, fih kart ala shanak, shakhs esmoh Effat Abdulkareem. [Respected principal, there is a card for you by the name Effat Abdulkareem.]

Principal: Oluh ana mush mawjood. [Tell HIM I'm not here.]

(Effat enters the scene)

Effat: Hadhrat alnadher? [Respected principal!]

Principal: Na'am! [Yes.]

Effat: Effat Abdulkareem. [She-teacher introduces her name while the principal is busy with something and giving his back to her.]

Principal: Huwa fain?! [Where's HE?] (Turing round seeking a man by the name Effat.) (Laugh track)

Effat: Ana ya fendem. [It is me, sir.]

Principal: Enta! Enta Effat Abdulkareem! Wilabs keda leih ya Effat! [You! You're

Effat Abdulkareem! Why are you wearing as such, Effat?!]

Effat: Wahdah set wa majestair fi alfalsafah. [It is a lady and she has an MA in Philosophy.]

Principal: Enti eli jay tedarasi endi fi almadrasah! [You're the one coming to teach with me in the school?]

Effat: Lu samaht. ([Yes, please.] 
Two violations of the quantity maxim are realized in the situation above. The first one is observed in the utterance of the school attendant who passed less information about the gender identity of the sheteacher to the principal. The attendant's use of the gender-neutral- noun 'shakhs' (person) is not informative enough to the principal about the feminine gender of the proper noun 'Effat'. The second violation is manifested in the utterance of the she-teacher in introducing herself as 'Effat Abdulkareem' without any reference to her feminine title 'anesa' (Miss) or occupation 'ostadh $\underline{A H}$ ' ( $\underline{\mathrm{SHE}}$-teacher). In fact, according to the Egyptian convention, the proper noun 'Effat' is a common name that is used to identify both male and female. Therefore, the less informative introductory words used by the school attendant and uttered by the she-teacher Effat account for the principal's failure to identify the feminine

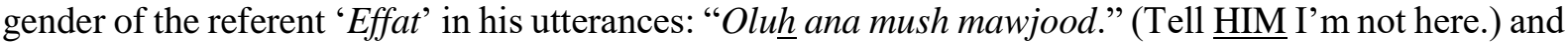
"Huwa fain?!" (Where's HE?). The situation as such presents itself as laughable for the audience.

\subsection{Violation of Quality Maxim}

The Maxim of Quality is concerned essentially with telling the truth. Its submaxims bid speakers not to say things which they believe to be false nor to say things that lack adequate evidence. 13 (21.4\%) violations of the maxim was reported in the analysis of the play. The following scene illustrates how the character violates the submaxim of telling false information in the play.

Situation 3: [The principal is investigating Mursi about his absence]

Principal: (Calling Mursi) Enta ya waled! [You, boy!]

Mursi: Ah ya nadher, enta ya nadher! [What, principal! you the principal!]

Principal: Enta lazm tetrefed. [You must be dismissed.]

Mursi: Laih! [Why!]

Principal: Bayez! Balek bara betkum talat ayam, abok aleb alek eskendaryah, tedar toul li kunt fin ya waled? [Spoiled! You have been away from your house for three days. Your father searched you everywhere in Alexandria. Can you tell me where you were, boy?]

Mursi: Ha... kunt fi Bairoot. [Um.... I was in Beirut] (Laugh track)

Principal: Ta'amel aih fi Bairoot?! [What were you doing in Beirut?!]

Mursi: Azaker ma'a wahed sahib. [I was studying with a friend of mine.]

Principal: Ya salam! Ma ta'arafsh tedhaker el fi ma wara al a'ali albehar. [Amazing! You can't study unless being over the seas.]

Mursi: Ma'andeesh Kitab joghrafya. [I don’t have geography book.]

In the scene above the principal asks one of the mischievous students, 'Murasi, about his whereabouts for three days of absence from the house. Mursi replies that he was in Beirut (The capital of Lebanon). The principal again asks Mursi what he was doing in Beirut. Mursi says that he was studying with a friend of his. The principal criticizes him for such ridiculous excuses. Amusingly, Mursi gives another false excuse that he doesn't have geography book. The violation of quality maxim lies in the character's recurring bold-faced lying in his consecutive responses. The character's responses that 'he was in Beirut' and 'he was studying with his friend' are considered incongruous; and that is shown in the sarcastic comments of the principal "Ya salam! Ma ta'arafsh tedhaker el fi ma wara al a'ali albehar (Amazing! You can't study unless being overseas)". Such incongruous responses create laughter among the audience. Another humorous effect of the character's response ' $I$ was in Beirut' is felt in its conversational implicature which is triggered in the audience's background knowledge about Beirut in 1970s. In fact, in the 1970s Beirut was famous for romantic relationship among youth. Using the word 
Beirut, the character conveyed the implied meaning that 'he was flirting with girls for the three days of his absence'.

Stating things that lack adequate evidence is the other submaxim of quality which was violated in the play. Consider the following scene which illustrates how this submaxim is violated.

Situation 4: [Mursi is passing the news to his friend, Lutfi that his defeat was announced in the BBC]

Mursi: Aza'o hazmti fi al bi bi si. [They have announced my defeat in the BBC.]

Lutfi: Ya qada! Mush ma'aqol alkalam eli betoulo deh! [Come on! Such news is impossible.]

Mursi: Ah Wallah! [Yes, I swear!]

Lutfi: Mumken ya kun dah hasal! [Could this happen?!]

Mursi: Alnhar dah alsubh fatahna alradio la'ena marshat askareh wa quran. [Today morning, when we turned on the radio, we found military parade and recitation of Holy Quran.] (Laugh track)

Lutfi: Alethnain! [Both of them!]

Mursi: Ba'ad shuwaih almuze'a beta'a alradio qam waqef al helu. [After a while, the announcer of the radio stood upright.]

Lutfi: Almuze'a maluh?! [What happened to the announcer?!]

Mursi: Waqef al helu. [Stood upright.]

Lutfi: Enta aih eli arafak anuh waqef al helu?! [How did you come to know that he stood upright.]

Mursi: La'ena alradio beya'mel keda ... [Because the radio was doing like this.... (Shaking his body)]. (Laugh track)

In the above quoted scene, the character, Mursi violates the submaxim of quality two times. The first time is observed in his utterance: fatahna alradio la'ena marshat askareh wa quran (when we turned on the radio, we found military parade and recitation of Holy Quran). This violation manifests itself in Lutif's reaction about the incongruous co-occurrence of both of the underlined events as he says: "Alethnain! (Both of them!)". Mursi's conveyed false information cannot be supported by concrete and visual evidence as he relied on a radio broadcast. The second time of violating the submaxim exists in the character's ridiculous utterance: almuze'a beta'a alradio qam waqef ala helu (After a while, the announcer of the radio stood upright). Likewise, the violation here lies in the character's inability to provide adequate evidence about the announcer's standing up in the radio when he was asked to prove that. Both situations created humorous effect on the part of the audience as they were heard producing canned laughter following the violation.

\subsection{Violation of Relevance Maxim}

According to the maxim of relevance (relation), a cooperative speaker should not convey any information that is not relevant in the context of the utterance. 14 (22.9\%) instances of laughter identified as the results of violation of relevance maxim in the play. The following are some illustrative examples about the violation of the maxim.

Situation 5: [In the scene teacher Effat is in dispute with the principal who refuses to give her the class timetable]

Effat: Hazrat alnadher an ayza jadwal alhesas beta'i. [respected principal, I want my class timetable!]

Principal: Ma endesh jadwal; rohi shofi leki madrasah tanyah. [I don't have 
timetable; you find another school for you.]

Effat: (Asking about the address of the school district) Mumken tateeni enwan almande'ah, le ani mesh men hena? [Could you give me the address of school district as I'm not from here?]

(Bahgat takes teacher Effat aside in couple holding arms-like)

Effat: Aywah? [Yes?]

Bahgat: Alnas kulaha betetklem alya ana wa enti wlazm nadha had lelesha'at. (Laugh track) [All the people are talking about both of us. We must stop the rumors.]

Effat: (Astonished of hearing such words) Enta ayez eh belzabt? [What do you want exactly?!]

Bahgat: Ana ayez rube'a jenaih. (Laugh track) [I want a quarter pound.]

The title of the situation above shows that the main topic of the scene is a dispute between teacher Effat and the principal who refuses to give her the class timetable. As a result of that dispute teacher Effat asks the principal about the address of the school district in order to report the matter. Astonishingly, in the course of their argumentation, the character, Bahgat takes the teacher aside and starts discussing an assumed self-created personal topic which is entirely unrelated to the main topic of the scene. Such a violation is followed by loud laughter on the part of audience. A part from that, Bahgat, in the interaction of the new topic, violates the concerned maxim by giving irrelevant and ridiculous answer to the teacher's question when she asks: Enta ayez eh belzabt? (What do you want exactly?!). He answers: Ana ayez rube'a jenaih (I want a quarter pound). Laugh track is heard in this context.

Another example of violating the maxim of relevance is given below:

Situation 6: [In the scene teacher Effat is writing the title of the lesson on the board and Mursi is smoking hookah]

Effat: Mursi! (Calling Mursi)

Mursi: (Nagging!) Yadeh alnelah! Mesh arfeen netalem wala netkyef fi albalad deh. (Replying) Na'am! [What the hell! We can neither learn nor relax in this country! Yes!]

Effat: Ta'lali hena shuwayah. [Come here for a while.]

Mursi: Allah! Huwa ana khadam beta'a abookum allilah deh. [Oh God! Am I a servant of your father tonight?!]

Effat: Balash elat adab wtal hena showayah. (Starring at the smoke coming from the side of Mursi) Eh dah ya awlad?! Aldukhan tala menain?! [Stop this misbehavior and come here! What's this, guys?! From where the smoke is coming out?!]

Bahgat: (Replying) Asluhom bebalatu alshare'a eli janbena. (Laugh track). Actually, they are paving the next street.

The scene above demonstrates some of the mischievous students' misbehaviors with the she-teacher. One of these misbehaviors is smoking hookah in the presence of the teacher. At the time teacher Effat discovers that there is smoke coming from the side of Mursi, she inquires into its source. She asks: Aldukhan tala menain?!(where is the smoke coming out from?!). Bahgat intentionally violates the maxim by giving irrelevant answer: asluhom bebalatu alshare'a eli janbena. (actually, they are paving the next street.). Such a violation created humorous effect among the audience as it was followed by laugh track.

\subsection{Violation of Manner Maxim}

Grice's maxim of manner requires that interlocutors should be perspicuous when engaged in conversation. They should avoid obscurity of expression and ambiguity, as well as make their conversational contributions in a brief and orderly fashion. As shown in the table above maxim of 
manner receives the highest percentage of violations in comparison to the other maxims. 24 (39.3\%) violations were identified in the play; they spread in the four submaxims. For the convenience of presentation and space limitation of the paper, three illustrative examples of the maxim violation will be discussed. The following is an example of humor coming from violating the submaxim 'avoiding obscurity of expression'.

Situation 7: [Lutfi and Mursi ask Mansour about the letter that he sent to Lutfi's girlfriend, Saheer]

Lutfi: (Addressing Mansour) Yabni benesal a'an aljawab elinta ba'atuh. [We are asking about the letter that you sent "to Saheer"].

Mansour: Ana aref aljawab deh ba'a. [I know this letter.]

Mursi: Eih aljawab deh! [What's this letter?]

Mansour: Enta aref albent Saheer eli fi almadrasa eli janbena? [You know the girl, Saheer who is in the neighboring school?]

Mursi: Aywah, malha deh? [Yes. What is there with her?]

Mansour: Sahait alsubeh, [I got up in the morning.]

Mursi: Sahait alsubeh! Awel marah ashoof wahed yes-ha alsubeh! [You got up in the morning! It's the first time for me to see a person getting up in the morning!]

Mansour: Ana kul mara asha alsubeh. [I every time got up in the morning.]

Mursi: Sahet alsubeh alsa'a kam? [At what time you got up in the morning?]

Mansour: Sahet alsubeh alsa'a sabah belail keda. (Laugh track) [I got up in the morning around at 7 O'clock in the evening.]

Mursi: Badri Keda! (Sarcastically speaking) [It is too early as such!]

The background of the scene above tells that the principal found a letter signed by Mansour and sent to Saheer (Lutfi's girlfriend). Lutfi and Mursi ask Mansour about the letter. Mansour gives them evasive and obscure answer. He states 'ana kul mara asha alsubeh (I every time got up in the morning). Being asked about the time of him getting up in the morning, he replies: "Sahet alsubeh alsa'a sabah belail keda (I got up in the morning at around 7 O'clock in the evening). The character's expression reveals that it is obscure. The obscurity of the expression lies in the incongruous coexistence of different timing, 'in the morning and in the evening'. The character's intentional violation of the submaxim brought about amusement among the audience who giggled at the back of the scene.

Avoiding ambiguity of expression is another submaxim of manner that was violated in the play. The following example shows how this submaxim is violated.

Situation 8: [In the scene Mursi describes his assumed experience to Bahgat about his giving tuition in Beirut]

Mursi: Wala ya Bahgat! [Hey, Bahgat!]

Bahgat: Ayeh? (What?)

Mursi: Ama an edait drous fi bairoot! [I gave tuition in Beirut!]

Bahgat: La ya shaikh! [No man!]

Mursi: Ya nahar sewed! Almugararat eli henak eyh! Mugarart sahla! Mush zai almugarart eli andina. Almugarar eli henak tulluh ta'al ya mugarar yeji ala tool. [What on earth! The courses there are wow! Easy courses! They aren't like the ones we have here. There, when you call the course to come to you, it comes directly.] 
The violation of the submaxim lies in the ambiguity of the utterance "Almugarar eli henak tulluh ta'al ya mugarar yeji ala tool (There, when you call the course to come to you, it comes directly). Here Mursi personifies the non-human noun 'Almugarar' (the course). Almugarar (the course) is given the quality of being able to interact to someone's call. The ambiguity of the utterance is reflected in Bahgat's funny bewildered facial look. However, it created humorous effect on the audience whose laugh was clearly heard. In fact, it is the audience's background knowledge about Beirut which paved the way for perceiving Mursi's figurative utterance in that girls in Beirut are easy to fall in love with.

Another violation of the maxim of manner can be illustrated with reference to the submaxim which enjoins interlocutors to be orderly in their conversational contribution. Below is an example about the violation of this submaxim.

Situation 9: [Teacher Effat enters the scene greeting the principal in the presence of the five mischievous students]

Effat: Sabah alkhair ya hadhret alnadher. [Good morning, respected principal.]

Principal: Khair! [What's there?!]

Bahgat: (Welcoming the teacher) Ahlen wsahlen! [Welcome!], (Shaking hands with her and introducing himself as the principal) An hadhrat alnadher, ayi khadamat? [I'm the respected principal, any service?]

Effat: (Shaking hands and starring at him) Ahlen wsahlen! [Welcome!]

Bahgat: (Shaking hands again) Masa alkhair.... Ana maiya sharabat hareemi akher halwa. (Pointing to something behind the teacher). [Good evening..... I have nice socks for ladies.]

(Bahgat moved aside and Mursi approached the teacher)

Effat: (Greeting Mursi as he approached her) Sabah alkhair! [Good morning!]

Mursi: Na'am! [Yes!]

Effat: (Greets him again) Sabah alkhair! [Good morning!]

Mursi: Laih! [Why!]

Effat: La abaden Ma feesh haja. [No, nothing]

Two cases of violation can be elicited from the situation above. The scene is opened with teacher Effat's 'Sabah el-Khair' (good morning) - greeting. Bahgat welcomes teacher Effat and introduces himself as the principal. Teacher Effat exchanges greeting with him. Surprisingly, Bahgat greets her again saying: 'masa alkhair' (good evening) and offers her ladies socks items that are presumably displayed for sale. The violation of the submaxim can be explained with reference to the incongruity of the established context. Bahgat's good-evening greeting is considered incongruous with the previously time-established greeting exchanges. Likewise, his offer to sell items is incongruous with the previously status-established image as the principal. Such disorderly utterances bewildered the teacher who remained silent and created humor among the audience. The other case of the submaxim violation is observed in Mursi's two responses: a) Na'am! (Yes!) b) Laih! (Why!) when teacher Effat greets him 'sabah Alkhair (good morning). In an orderly communication, people normally adhere to an adjacency pair exchange. For instance, a greeting requires to be followed by a greeting response pair. Mursi's responses to teacher Effat's greeting are counted violations. These responses were followed by laugh track as they amused the audience. 


\section{Conclusions}

The study aimed at exploring the violation of Grice's maxims in the Arabic comedy Madraset AlMushaghbeen (School of Troublemakers). It attempted to explain how the violation of the maxims brings about humorous effects in the play. The study analysis demonstrated that 61 instances of maxims violation were identified in the play. Maxim of manner receives the highest percentage of violation i.e., 24 (39.3\%) compared to the other maxims. Maxims of relevance and quality come next, i.e., 14 (22.9\%) and 13 (21.4\%). Maxim of quantity constitutes 10 number of violations (i.e., 21.4\%). The study findings indicated that most of humorous situations derived from the maxim violations are perceived through the following: rhetorical strategy of overstatement and personification, use of misleading conventionalcoded expressions, incongruity of conversation-established concepts/ideas, and breaking of communication norms. The study findings also revealed that cultural and background knowledge contribute significantly in eliciting the humorous implicatures from the characters' utterances. In light of the study discussion of the maxim violations coincided with laugh track, it can be concluded that there is tangible evidence subscribing to the point that some of the humor in the scenes of the Arabic comedy, come from implicatures involving the characters' violation of Grice's maxims. Based on the findings of the study, the following implications can be drawn: humorous implicature depends on the conventions of the speakers' community and the language shared among them; and it arises as a result of speakers' acts and/or expressions that tend to be incongruous with the behavior and concepts established in the culture of the concerned interlocutors. This study creates an avenue for future researches in understanding the relationship between violations of Grice's maxims and humorous implicatures in different genres and across cultures. Therefore, further studies are suggested to explore implicatures derived from maxims violation related to cultural-specific behavior or norms in other genres.

\section{Ethics Committee Approval}

The author(s) confirm(s) that the study does not need ethics committee approval according to the research integrity rules in their country (Date of Confirmation: June 02, 2020).

\section{Acknowledgments}

I would like to thank Dr. Ashraf Atyah Hashim (Arabic Literature) and Dr. Nabil Al-Bakili (English Literature), Al-Baha University, for their constructive feedback in the data analysis of the study.

\section{References}

Ahmed, Mazin. (2007). On the relationship between Grice's maxims and humorous discourse. Journal of Adab AL-Rafidayn, 45(1), 49-66.

Al Kayed, M. (2019). An analysis of Jordanian jokes: A pragmatic study of humour. Global Journal of Arts, Humanities and Social Sciences, 7(1), 13-20.

Attardo, Salvatore (1994). Linguistic theory of humor. Berlin and New York: Mouton de Gruyter.

Benton, H. (ed.). (1983). The new encyclopedia britannica: Macropedia knowledge in depth volume 9. Chicago: William Benton Pub. 
Chen, R. (1993). Conversational implicature and poetic metaphor. Language and Literature, 18, 53-74.

Grice, P. (1975). Logic and conversation. In P. Cole \& J.L. Morgan (Eds.), Syntax and semantics: Speech acts (pp..41-58). New York: Academic Press.

Hassan, B. (2013). The pragmatics of humour: January 25th revolution and occupy wall street. Mediterranean Journal of Social Sciences, 4(2), 23-39. http://dx.doi.org/10.5901/mjss. 2013. v4n2p551

Hu, S. (2012). An analysis of humour in the big bang theory from pragmatic perspectives. Theory and Practice in Language Studies, 2(6), 1185-1190. http://dx.doi:10.4304/tpls.2.6.1185-1190

Ibraheem, S and Abbas, N. (2016). A pragmatic study of humor. Australian Advances in Language and Literary Studies, 7(1), 80-87. http://dx.doi.org/10.7575/aiac.alls.v.7n.1p.80

Jensen, Kim Ebensgaard. (2009). Humor. AAU: Almen Engelsk. Retrieved on April 26, 2020 from: https://www.slideshare.net/imagenesderisa/humor-54920203.

Leech, G. (1983). Principles of pragmatics. London: Longman.

Schwarz, Jeannine. (2010). Linguistic aspects of verbal humor in stand-up comedy. (Unpublished dissertation). der Universität des Saarlandes, Saarbrücken.

Taberski, D. (1998). A Gricean analysis of a situation comedy. MA thesis, California State University, San Bernardino.

Thomas, J. (1995). Meaning in interaction: An introduction to pragmatics. Essex, England: Longman.

Yule, George. (1996). Pragmatics. Oxford: Oxford University Press.

\section{Arap komedisi Madraset El-Moshaghbeen'deki Grice ilkelerinin ihlali ve mizahi etkileri}

\section{Öz}

Bu yazının amac1, Arap komedisi Madraset Al-Mushaghbeen'deki Grice'in ilkelerinin ihlalini araştırmak ve bu ihlallerin oyuna nasıl mizahi etkiler getirdiğini açıklamaktır. Analizler, oyunda 61 maksim ihlal örneğinin tespit edildiğini göstermektedir. Tarz ilkesi, diğerlerine klyasla en yüksek ihlal yüzdesini yani 24 (\% 39.3) oluşturmaktadır. İlgi ilkesi 14 (\% 22.9) ve nitelik ilkesi 13 (\% 21.4) onun arkasından geliyor. Nicelik ilkesi 10 ihlal sayısını (yani,\% 21.4) oluşturur. Çalışma, esprili durumlar yaratan maksim ihlallerin çoğunun şu şekilde algılandığını göstermektedir: retorik abartma ve kişileştirme stratejisi, yanıltıcı geleneksel kodlu ifadelerin kullanımı, konuşmaya dayalı kavramların / fikirlerin uyuşmazlığı ve iletişim normlarının kııılması. Çalışma aynı zamanda kültürel ve arka plan bilgilerinin karakterlerin ifadelerinden mizahi çıkarımlar yaratmaya önemli ölçüde katkıda bulunduğunu ortaya koyuyor. Çalışma aşağıdaki çıkarımlarla sonuçlanmıştır: mizahi etki konuşmacı topluluğunun kurallarına ve aralarında paylaşılan dile bağlıdır; ve konuşmacıların ilgili muhatapların kültüründe oluşturulan davranış ve kavramlarla tutarsız olma eğilimi ve / veya ifadeleri sonucunda ortaya çıkar.

Anahtar Sözcükler: ihlal; Grice ilkeleri; mizahi etkileri; komedi; işbirliği ilkesi 


\section{AUTHOR BIODATA}

Hameed Yahya Al-Zubeiry is an associate professor of Applied Linguistics at Al-Baha University, Faculty of Science and Arts- Baljurashi- Al-Baha, KSA. He received his Ph. D in Applied Linguistics from Hyderabad Central University in 2005. He has published a number of research papers in international and national journals of Linguistics \& Applied Linguistics Studies. He has reviewed research papers for some scholarly national and international journals. He has supervised some MA theses in Applied Linguistics. He also refereed a number of Scientific achievements for the promotion to associate professor post. His areas of interest include interlanguage, discourse analysis, pragmatics, socio-psychological studies, sociolinguistics, English Language Teaching (ELT), and second language acquisition. 